\title{
Approaches to the Different Levels of Consumer Protection in European Contract law, focusing on Food Safety Regulations
}

\author{
Gael Langosch
}

\section{Introduction}

Through cheap airline tickets and online stores the world is becoming smaller and smaller every day, in the sense that it is easier to travel around the globe or to get goods from a foreign country, than it has ever been before. The strive to harmonise the existing contract laws of the Member States of the European Union (EU) seems therefore to be a reasonable step as it will make it easier for business and consumers to conclude contracts with parties from other Member States without having to worry about the applicable national law.

In the area of contract law an important aspect is consumer protection, on the national and European level, which involves cross border elements. Within the European Union Directives and Regulations secure a minimum level of protection for the consumer. These laws are designed to prevent business to gain by fraud or unfair practices; they protect the weaker party, the consumer, from the stronger party, the businesses.

In Article 2 (B) of Directive 93/13/EEC on unfair terms in consumer contracts, a consumer is defined as "any natural person who, is acting for purposes which are outside his business, trade or profession."”

To achieve the optimal level of consumer protection within the EU, in order for the internal market to work properly; the aim of this paper is to address the following research question: "How to approach the differences in level of Consumer protection, in a civil law country compared to a country under the common law regime?". In order to be able to outline some of the differences the issue of food safety will be used as a case-study.

1 Directive 93/13/EEC, [1993] O.J. L.95/29. 
A harmonized set of rules on European contract law would create a set of uniform conditions for the contracting parties in Europe; it would minimise the risks since the parties would not have to choose or be submitted to an unknown legal order and furthermore it would save transaction costs to the contracting parties on a cross-border basis. ${ }^{2}$

If the internal market is to function effectively and provide benefits for the consumer, a high level of consumer protection is crucial. In this respect private law is an important means to achieve the objective. Consumers can be protected through contract law by interfering in the process of contracting and providing a high level of protection within the contract. There are however also other means, which help to provide consumer protection. An important element in this field is the standardisation of the functioning of contract law at the level of the EU.

A case-study on food law will be provided to exemplify some of the differences between a country under the common law regime (UK) and a country under the civil law regime (Germany). Food and foodstuff serve as a great example in this field, due to the high achievements in this area. In relation to the case-study it should be noted that in all of the Member States, the general principles concerning food safety and consumer protection are dealt with on a national level. On the $28^{\text {th }}$ of January 2002 the European Parliament (EP) and the Council adopted Regulation 178/2002 laying down the general principles and requirements of food law, establishing the European Food Safety Authority and laying down procedures in matters of food safety. ${ }^{3}$ The aim of the Regulation is to provide a framework to ensure a coherent approach in the development of food legislation. It also provides the general framework for the areas that are not covered by specific harmonised rules but where the functioning of the Internal Market is ensured by mutual recognition. ${ }^{4}$

In relation to standards for food safety, EU law makes sure that the products that are sold have a minimum standard and the laws ensure that these products are safe. Food safety is based on the principle that the whole "food chain" is taken into account in order to ensure safety. EU food safety laws regulate how farmers produce, how food is processed, what colourings and addictives can be used in them and how the food is sold. ${ }^{5}$

Furthermore EU laws on food labelling ensure that the consumer knows what he is eating. A full list of ingredients must be given on the label, along with details on colouring

2 Reich, p. 81.

3 Regulation 178/2002, [2002] O.J. L 31.1.

4 Regulation 178/2002, [2002] O.J. L 31.1 Article 1.

5 Health \& Consumer Protection Directorate- General 'Consumer Protection in the European Union: Ten Basic Principles' p.5. 
preservatives and so on. EU food labelling laws also regulate which products can be labelled as being "organic" or other labels. ${ }^{6}$

The focus will be on the laws regulating food labelling and misleading information in the chosen countries.

It can be argued that harmonisation of the law would mostly be beneficial for the contracting parties, however a document comprising the already existing laws at the European level and the laws of the Member States on the issue would need to be drafted, in order to achieve the optimal level of consumer protection possible within the EU. In the next Section a few reasons why harmonisation is beneficial will be given. In order to provide an idea on how to approach the differences in consumer protection that exist at a national level, an outline of the existing European laws, securing consumer protection, will be given, followed by the laws on food safety at the European level. In order to be able to provide an outline on how best to approach the differences that might exist between the two national regimes in the field of consumer protection, with the focus on food safety, one needs to keep in mind the existing laws that have been issued in the field by the EU. It can be said that if the laws of the EU have been implemented at the national level of the Member States, the level of consumer protection will be the same at the national level as it is at the European level.

To be able to compare the two chosen countries, the existing law on consumer protection in Germany, a country under the civil law regime, will be given, followed by the regulations on foodstuff at the national level. The same will be provided for the laws on consumer protection and foodstuff, as a case-study, of the United Kingdom, which will serve as an example of a common law regime.

Food safety regulations will be addressed to show how the consumer is protected in the named field and to exemplify some differences between the protections of the consumer under the two regimes. The focus here will mainly be on food labelling and misleading information, furthermore risk assessment and risk management at national level will also be addressed shortly, however they are not part of the direct comparisons. The focus of the paper will be on the statutory law of the two countries and the EU. Next some ideas will be provided on how to approach the differences that might exist between the two regimes. A direct comparison of the two countries in relation to food labelling will be provided in the annex. Lastly a short conclusion will be provided.

6 Regulation 1169/2011, [2011] O.J. L. 304/18. 


\section{Reasons for the Harmonisation of Contract Law}

To achieve the highest level of consumer protection within the EU in order for the internal market to work properly, it can be argued that a set of harmonised rules in the field is desirable and necessary, therefore some information on the process and the limitations to harmonization need to be provided, and reasons why harmonisation is a good step to take in the future.

The idea of a single set of rules is not a new phenomenon already some 2,000 years ago Cicero wrote:

'There shall not be one law at Rome, another at Athens, one now, another thereafter, but one everlasting and unalterable law shall govern all nations for all time.'7

Over the years there have always been emperors who tried to have one law governing their whole empire, instead of single set of rules within the different regions. When Roman Law was rediscovered, reshaped by the Glossators and taught in Bologna during the High Middle Ages, Ciceros dream of a single uniform set of laws came astonishingly close to being fulfilled. The law that developed thereafter had a relatively uniform approach to the science of law, however the ius commune from the Middle Ages stated to fade away with the rise of nation states and national law. ${ }^{8}$

At the moment the existing contract law within the EU is of great diversity, which is only natural with there being 27 Member States, each having their own system of law. In addition to the contract law of the 27 Member States there is also the law issued by the EU itself, adding yet another regime to the list. The differences in the regimes of contract law have promoted the idea of a harmonised regime, greatly over the last few years. A contracting party that is interested to deal with a party from a different country may be deterred to do so simply because of the different legal system in the other country. On the same note a consumer might decide not to buy a product online or on the other side of the border, because he might fear the foreign law that will apply to the contract. If a party still decides to contract, this will most likely end up to be more expensive than if the party

7 Ciceronis, 3.22.33.

8 Goode 2003, p.3. 
would have done so within the law of its home country. Ole Lando has expressed his views on the matter by stating that:

'The Union of today is an economic community. Its purpose is the free flow of goods, persons, services and capital. The idea is that the more freely and more abundantly these can move across the frontiers, the wealthier and happier we will become. All of these move by way of contracts. It should, therefore, be made easier to conclude and perform contracts and to calculate contract risks. (... ) Foreign laws are often difficult for the businessmen and their local lawyers to understand. They may keep him away from foreign markets in Europe. (... ) The existing variety of contract laws in Europe may be regarded as a non-tariff barrier to trade.' 9

Parties therefore often choose to smooth out this problem by setting the terms for the contract themselves and choosing the applicable law. However this does not prevent the national mandatory rules, which would be applicable in accordance with the conflict of law rules, to apply. ${ }^{10}$ The party will still have to take legal advice concerning the unknown applicable law, which in turn will be costly for the party.

Before going into further detail about the process and limitations of harmonisation an explanation of the distinction made by EU lawyers in relation to "minimal/minimum" and "full" harmonisation has to be outlined. The terms "minimum" and "full" harmonisation are used when a piece of law, usually a Directive or a Regulation, is implemented into the national law of a Member State, however much depends in the end on the scope of application of the specific EU legislative instrument."

The concept of minimum harmonization entails that a mandatory basis for the relevant topic/issue is provided; it sets a threshold which national legislation must meet. However the national legislator may still exceed the level or law provided for by the piece of law. ${ }^{12}$

Under full harmonization on the other hand, the harmonized standard replaces and eliminates the national standards entirely, regardless whether the national standard is higher or lower. ${ }^{13}$

\footnotetext{
9 Lando 2000, p.61.

10 Smits 2012, p.474.

11 Reich 2011, p.58.

12 Gomez \& Ganuza 2011, p.17.

13 Ibid.
} 
The existing legislation on consumer law, issued by the EU, has so far mainly been limited to relations between consumers and (professional) suppliers. Those EU consumer contract laws are limited to "bilateral relations", which refer to the relation between the consumer and a supplier. ${ }^{14}$ As mentioned above according to Article 2(B) of Directive 93/13/EEC on unfair terms in consumer contracts, a consumer is defined as "any natural person who, is acting for purposes which are outside his business, trade or profession." ${ }^{15} \mathrm{~A}$ business on the other hand is defined as "an organization involved in the trade of goods and services or both to consumers".

The Member States within the EU have used different, mostly broader, definitions of the terms "consumer" and "supplier/business". This is why the harmonised contract law will have to include both Business-to-Business transactions as well as Businessto-Consumer transactions and include a definition of the terms that is inline with the Member States perspective of the terms.

It still needs to be outlined what the reasons are to seek for harmonization of contract law within the EU. One major reason is that there is an increase in cross-border transactions. Businesses do not only trade within the boarders of their country any more but they trade on the level of the global market. Within a so-called global economy, the national boundaries are assumed to have far less significance. A harmonized law of contract would make those transactions easier and would increase legal certainty, for both parties. ${ }^{16}$

Furthermore, as mentioned before the argument that the contracting party does not wish to contract with another party simply because of the differences that exist between the various national regimes of contract law, is an other reason why harmonization is desirable. Once again it would offer the consumer legal certainty since the laws regulating the contract would be the same for contracts concluded with the national law of the country and with cross-border contracts. ${ }^{17}$

Another reason why harmonization is desirable, is that national law might be unsuitable for international transactions. In general within the EU the quality of the national contract law regimes is high, however there might be provisions within a national system that are not suitable for an international transaction. Ole Lando gives in "The Lex Mercatoria in International Commercial Arbitration" the example of a provision in the

14 Reich 2011, p.59.

16 Vogenauer \& Weatherill 2006, p.14.

17 Ibid. 
Scandinavian Sales of Goods Act, which provides that the consumer/buyer who 'wishes to invoke a late delivery of goods must give notice immediately upon delivery'.18 According to Lando this rule is not suitable for international sales since it my act as a 'trap' for the nonScandinavian consumer who are unaware of the existence of such a rule. ${ }^{19}$ Every national contract regime has rules of this nature. They do not cause a problem at the national level however for the consumer that does not have any knowledge of the national law, they can cause strong problems.

There are far more reasons why harmonization of contract law within the European Union is beneficial, however they will not all be listed at this point.

\section{Existing Legislation in the field of consumer protection of the EU}

Over the years the EU has issued a compact amount of rules in the field of contract law, which all further cross-border transactions and aim to secure a minimum level of protection for the consumer within the specific field in which the law is issued. Directive 1999/44/EC on certain aspects of the sale of consumer goods and associated guarantees, Directive $97 / 7 /$ EC on the protection of consumers in respect of distance contracts, Directive 2005/29/EC concerning unfair business-to-consumer commercial practices in the internal market and Directive 93/13 on Unfair Terms in Consumer Contracts, which secures a high level of protection for the consumer, serve as a good example of the great amount of legislation, that has been issued in the field by the EU. The Directive on Consumer Protection is of high importance in the field of consumer protection, it replaces Directive 97/7/EC and Directive 85/557/EEC. ${ }^{20}$ The Proposal on the Common European Sales Law will also be addressed. In this section some of the existing Legislation that secures protection for the consumer in the field of contract law will be outlined. It is necessary to address the legislation that exists at the European level on the issue in order to be able to provide ideas on how to approach the differences that exist at the national level.

\footnotetext{
18 Lando 1985, p. 453 .

19 Ibid.

20 Directive 2011/83/EC, [2011] O.J. L. 304/64.
} 


\subsection{Directive 93/13/EEC}

To begin with Council Directive 93/13/EEC on unfair terms in consumer contracts is of high importance in this field, it applies to contracts concluded between a seller and a consumer. ${ }^{21}$ Article 3 of the Directive defines a "contractual term, which has not been individually negotiated" as unfair, furthermore a definition of what constitutes the concept of "not been individually negotiated" is given in Section 2 of the Article. The Directive introduces a notion of good faith, without which a contractual term can also be declared as being unfair. The notion of good faith in the Directive prevents a significant imbalance in the rights and obligations of the consumer on one hand and the seller on the other hand. Article 6 ensures that unfair contractual terms are not binding upon the consumer and that necessary measures are taken by the Member States to secure the protection of the consumer. The Directive was one of the first to push for a reduction of cross-border barriers to trade within the internal market. The legislation addressed the issue on how to strike a proper balance between respecting the freedom of the parties to choose the terms of their contract and controlling unfair terms inserted into contracts by the stronger party, namely the business. The Directive aimed at encouraging the consumer to engage in shop abroad. ${ }^{22}$

\subsection{Directive 1999/44}

Likewise Directive 1999/44/EC on certain aspects of the sale of consumer goods and associated guarantees, aims to harmonise those parts of the consumer contract law regimes that concern legal guarantees, providing high standards of protection for the consumer. In the preamble it states that the seller is directly liable to the consumer for the conformity of the goods with the contract. The aim of the Directive is the 'approximation of the laws, regulations and administrative provisions of the Member States on certain aspects of the sale of consumer goods and associated guarantees in order to ensure a uniform minimum level of consumer protection in the context of the internal market.'23 Article 2 of the Directive protects the consumer by requiring that the seller delivers the goods to the consumer which are in conformity with the contract of sale. Furthermore Article 3 of Directive 1999/44 provides a list of rights of the consumer, which again secure high level of protection for him.

21 Directive 93/13, [1993] O.J. L 95/29, Article 1.

22 Collins 2008, p.2.

23

Directive 1999/44/EC, [1999] O.J. L 171/12 Article 1. 


\subsection{Directive 97/7/EC}

Similarly to the two Directives mentioned above, Directive 97/7/EC on the protection of consumers in respect of distance contracts, also secures protection for the consumer. The aim of the Directive is to put consumers, which have purchased goods or services through distance communication, in a similar position to consumer who have bought goods or services in local shops. ${ }^{24}$ The term 'distance contract' is defined as 'any contract concerning goods or services concluded between a supplier and a consumer under an organized distance sales or service-provision scheme run by the supplier, who, (...), makes exclusive use of one or more means of distance communication up to and including the moment at which the contract is concluded'. Where the Directive applies, the consumer is given high level of protection, however Article 3 contains a list of exemptions to which the Directive does not apply.

\subsection{Directive 2005/29/EC}

The purpose of Directive 2005/29/EC, concerning unfair business-to-consumer commercial practices in the internal market, is to 'contribute to the proper functioning of the internal market and achieve a high level of consumer protection by approximating the laws, regulations and administrative provisions of the Member States on unfair commercial practices harming consumer's economic interests' as stated in Article 1 of the Directive. The Directive only applies to business-to-consumer contracts and not to business-to-business contracts, however since the focus of this paper is on consumer protection the fact that business-to-business contracts are not included is of no importance. Within Article 5 the Directive provides the prohibition of unfair commercial practices, which in turn offers high protection for the consumer. ${ }^{25}$

\subsection{Directive 2011/83/EC}

Lastly a look at Directive 2011/83/EC on consumer rights will be taken. It replaces Directive 97/7/EC on the protection of consumers in respect of distance contracts, Directive 85/557/ EEC to protect consumer in respect of contracts negotiated away from business premises. ${ }^{26}$ The Directive offers, a high level of consumer protection, this can be seen in Article 1, which outlines the subject matter of the Directive. 'The purpose of the Directive is, though the achievement of a high level of consumer protection, to contribute to the proper

\footnotetext{
24 Directive 97/47/EC, [1997] O.J. L 144/19.

25 Directive 2005/29/EC, [2005] O.J. L 149/22.

26

Directive 2011/83/EC, [2011] O.J. L. 304/64.
} 
functioning of the internal market by approximating certain aspects of the laws (...)'. The Directive covers any contract concluded between a supplier/trader and a consumer. According to Article 4 Member States are not allowed to maintain or to introduce, at the national level, any provisions diverging from those laid down in the Directive.

\subsection{Common European Sales Law}

The proposal for the Common European Sales Law has been issued in 2011 and provides for an optional regime of contract law to choose for by the parties. The Regulation provides for a single set of contract law rules, to be used for cross-border transactions, if chosen for by the parties. It will enable the traders and consumer to rely on a common set of rules, reducing costs and providing a high degree of legal certainty. In addition the Regulation contains a comprehensive set of consumer protection rules, in order to ensure a high level of consumer protection. The clause contained in the Proposal, declaring the Regulation optional, is inappropriate to secure high level of consumer protection in a Business-toConsumer contract since a decision against the CESL will easily be taken if this would require the business to secure higher level of protection for the consumer it wants to contract with. In this paper the point of view will be taken that the Member States have agreed to harmonise their regimes of contract law and set beside the national legislation on the field. The Common European Sales Law will be sued as the "starting point", the clause making the Proposal optional will therefore be seen as not existing and therefore no further attention will be paid to it. ${ }^{27}$

Finally it can be said that the mentioned law, which has been issued by the EU secures high levels of consumer protection, however as of now, they stand next to the national contract law regimes of the Member States. The aim of this paper is to find a solution on how to approach the differences in consumer protection of two countries in case of harmonisation, keeping the already existing EU legislation on the matter in mind.

\section{Food Safety Regulation issued by the EU}

To point out some of the major difference, in relation to the food safety regulations between the civil law system on consumer protection and the common law system on

$27 \operatorname{COM}(2011) 635$ final. 
consumer protection it first need to be outlined which legislation in this field is already in place at the European level. An outline of how to best approach these differences will be provided at a later point.

As mentioned before the general principles concerning food safety and consumer protection are dealt with on the national level of the Member States, which is why it serves as a perfect example to outline the different levels of protection that exists. National food safety regulations do however often constitute barriers to trade, which hinders the proper functioning of the internal market of the EU. It is only natural that the Community therefore issued legislation in order to provide the proper functioning of the internal market and to eliminate the barriers that may arise due to national legislation in the field..$^{28}$ In relation to standards for food safety, EU law makes sure that the products that are sold have a minimum standard and the laws ensure that these products are safe.

\subsection{Regulation $178 / 2002$}

On the $28^{\text {th }}$ of January 2002 the European Parliament and the Council adopted Regulation $178 / 2002$ laying down the general principles and requirements of food law, establishing the European Food Safety Authority and laying down procedures in matters of food safety, also known as the 'General Food Law'.29 Over the years it had become clear that the reform of the scientific committee system had not been enough to restore the confidence in the EU regulations, which is why the European Food Safety Authority was established alongside the Regulation. The European Food Safety Authority has as one of its main objectives to address the problem of confidence by guaranteeing more independence and excellence and to provide greater transparency. ${ }^{30}$

The aim of the Regulation is to provide a framework to ensure a coherent approach in the development of food legislation. It also provides the general framework for the areas that are not covered by specific harmonised rules but where the functioning of the internal market is ensured by mutual recognition. ${ }^{31}$

The food law pursues a high level of protection of human life and health and the protection of the consumer, as outlined in Article 5 (1) of the Regulation. Furthermore Article 6 requires food law to be based on risk analysis in order to achieve the general objective of a high level of protection of human life and health.

\footnotetext{
28 Vos \& Wendler 2006, p.67. 
At the heart of the food policy of the 'General Food Law' lays the risks analysis as outlined in Article 6 of the Regulation. ${ }^{32}$ According to the Regulation the primary responsibility for food safety lies with the food and feed business operators. It is the duty of the operators to guarantee that at all stages of the production, processing and distribution of the products, they fulfil the requirements of food law. Furthermore the operator is required to withdraw any product from the market, if there is reason to believe that the products do not satisfy the prescribed safety requirements..$^{33}$ Risk assessment consists, of a scientifically based determination of a potential hazard, encompassing hazard identification, hazard characterisation, exposure assessment and risk characterisation, which is outlined in Article 3. When it comes to harmonisation of approaches to risk assessment, the major difficulty that has been encountered in the attempts to integrate the results of risk assessment of different national food safety authorities is that, most of the national authorities of the Member States apply their own methodologies in carrying out these risk assessments. ${ }^{34}$

In addition the Regulation also includes an Article dealing with the protection of the interests of the consumer.

Moreover the 'General Food Law' Regulation provides for a set of general requirements of food law in Section 4 of Chapter II of the law.

\subsection{Regulation 1169/2011}

The EU has also introduced laws on food labelling, to ensure that the consumer knows what he is eating. A full list of ingredients must be given on the label, along with details on colouring preservatives and so on. EU food labelling laws also regulate which products can be labelled as being "organic" or other labels. Regulation No 1169/2011 on the provision of food information to consumers, contains such laws on food information to consumers. 35

As outlined in Article 1 of the Regulation, a 'basis for the assurance of a high level of consumer protection in relation to food information, taking into account the differences in the perception of consumers and their information needs whilst ensuring the smooth functioning of the internal market', is given by the Regulation. In addition Article 6 addresses the general food information requirements and responsibilities of food business operations and outlines the basic requirements of food labelling. According to

32 Vos \& Wendler 2006, p.72.

33 lbid.

34 Vos \& Wendler 2006, p.85.

35

Regulation 1169/2011, [2011] O.J. L. 304/18. 
the Article any food that is intended for the final consumer has to be accompanied by food information, which is in accordance with the Regulation.

An extensive list of definitions is given in Article 2 of the Regulation, defining amongst others the terms 'mandatory food information', 'repacked food', 'ingredients' and the term 'labelling'.

Food information law requires mandatory food information which concerns the information on the identity and composition of the food, the information on the protection of consumers' health and the safe use of a food and information on nutritional characteristics in order to enable the consumer, to make informed choices, as outlined in Article 4 of the Regulation.

In addition Article 7 requires fair information practices, by stating that the information on food is not supposed to be misleading in relation to the characteristics of the food, by attributing effects or properties which it does not possess, by suggesting that the food posses special characteristics which is does not have and by suggesting, by means of appearance, that ingredients are present which are in reality not contained in the food. Furthermore Article 7 requires food information to be accurate, clear and easy to understand.

Lastly Chapter IV of the Regulation gives a detailed outline on the mandatory food information, dealing with the content and presentation in Section 1, the detailed provisions on mandatory particulars in Section 2 and the nutrition declaration in Section 3.

The above-mentioned Regulations are the only EU legislation concerning food law that will be discussed at the moment. The focus at the national level will be to see how the consumer is protected in relation to misleading information on foodstuffs and the labelling of the products, risk assessment and risk management will also be addressed.

\section{Germany}

\subsection{Consumer Protection}

Under the German regime of contract law there is no solid consumer protection act as such, but the consumer finds protection in several individual laws, the German Civil Code, the Bürgerliches Gesetzbuch (BGB), for example contains several paragraphs dealing with contracts as such. In relation to food law there are however individual acts lying down the law and regulations concerning for example food labelling. 
Under German law the definition of a consumer contains almost the exact same wording as the definitions that can be found in the various directives issued by the EU. The similarity in the wording exists because Section 13 of the German Civil Code serves to implement Council Directive 85/577/EEC to protect the consumer in respect of contracts negotiated away from business premises, ${ }^{36}$ Council Directive 87/102/EEC for the approximation of the laws, regulations and administrative provisions of the Member States concerning consumer, ${ }^{37}$ Council Directive 93/13/EEC of 5 April 1993 on unfair terms in consumer

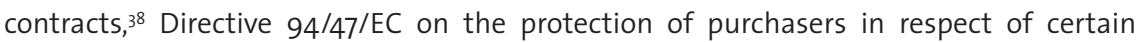
aspects of contracts relating to the purchase of the right to use immovable properties on a timeshare basis, 39 Directive 97/7/EC of the European Parliament and of the Council of 20 May 1997 on the protection of consumers in respect of distance contracts ${ }^{40}$ and Directive 1999/44/EC on certain aspects of the sale of consumer goods and associated guarantees. ${ }^{41}$

Section 13 of the BGB on the consumer provides the following definition: 'A consumer means every natural person who enters into a legal transaction for a purpose that is outside his trade, business or profession.'

Section 242 of the German Civil Code introduces the notion of good faith and requires the obligor to act in accordance with the requirements of good faith, taking customary practice into consideration, all contracts are to be interpreted 'as required by good faith, taking customary practice into consideration, as outlined in Section 157 BGB. The notion of good faith under German law is linked with the notion of 'Treue und Glauben', the German Civil Code does however not provide a definition for the notion of good faith.

While reading through the German Civil Code it becomes highly obvious that a great amount of the legislation that is in place, in relation to consumer law, is in favor for the consumer. It can be concluded that the German regime provides high protection for its consumers. Even though there are a number of provisions in place in order to secure protection for the consumer it is not relevant to list them all at this point, since they are concerned with all different fields of the law. In order to provide a more detailed idea of how the consumer is protected under the German regime of consumer contract law, the legislation on food safety will be outlined.

\footnotetext{
36 Directive 85/577/EEC, [1985] O.J. L.372/31.

37 Directive 87/102/EEC, [1987] O.J. L.42.

38 Directive 93/13, [1993] O.J. L 95/29.

39 Directive 97/47/EC, [1997] O.J. L 144/19.

40 Directive $97 / 7 / E C$, [1997] O.J. L.43. 


\subsection{Food Safety Regulations in Germany}

The first step in the history of food safety regulations in Germany was taken in 1876, when the Imperial Health Administration, Kaiserliches Gesundheitsamt, was created. The agency was established in order to create a more centralised system of food controls. Moreover in 1879 the first general law on food safety and consumer goods was adopted, it introduced a new type of state-sponsored research on food safety..$^{42}$ The basic set up for the food safety regulations in Germany remained the same through out the Weimer Republic and under the National-Socialist rule. One major change was the successor institution the Reichsgesundheitsamt (RGA), as the main state agency for research and monitoring compliance. ${ }^{43}$ The outbreak of BSE in the winter of the year 2000 caused an elementary change in the field of food safety regulation in Germany. Germany adopted a separation of risk assessment and risk management after the outbreak of Bovine spongiform encephalopathy (BSE), a functional as well as an institutional separation of the two main elements of risk regulations were adopted. This corresponded to the scientific as well as the political aspects of risk regulation. In addition two new federal agencies were established, the Federal Agency of Consumer Protection of Food Safety (BVL) and the Federal Institute of Risk Assessment (BfR). The new agencies were seen as being more compatible with the structure provided for by the EU in relation to food safety regulation and to be better suited to manage food safety issues at the national level. 44

In relation to food safety there has been a state-wide process of centralisation, which serves to harmonise the food safety regulations on the level of the Länder in Germany. A common standard has been introduced to secure the process of harmonisation of the Länder. The idea is widely appreciated, however there remain issues in co-ordination between the federal and the state level, resulting in still sixteen different ways of handling and controlling food safety issues. Due to the fact that EU legislation supersedes national legislation, any new legislation in the field of food safety regulations must be implemented. The Federal Ministry for Food, Agriculture and Consumer Protection is in charge of the correct implementation of the laws in this field. ${ }^{45}$ The legal framework in the field of food safety is established by the law on food, consumer goods and feed, the named law has been enacted to transpose the requirements of Regulation 178/2002.

\footnotetext{
42 Wippermann 2001, p.3. 
As mentioned before Germany adopted a separation of risk assessment and risk management after the outbreak of BSE, in relation to risk assessment the Federal Institution for Risk Assessment, Bundesinstitut für Riskobewertung, is in charge. The institution issues recommendations in numerous areas, for example in the field of food licensing, however it does not issue the guidelines on its own. Recipients of the recommendations are the federal agency responsible for tasks of risk management and the Ministry.

The Federal Ministry deals with risk management in Germany for food, agriculture and consumer protection, it is in charge of consumer protection, including food safety. In addition the newly created Federal Agency for Consumer Protection and Food Safety, which is defined as an independent agency for the conduct of risk management and authorisations acting with the field of mission of the Ministry, by Paragraph 1 of the Gesetz über die Errichtung eines Bundesamtes für Verbraucherschutz und Lebensmittelsicherheit, is also in charge of Risk Management.

The main goal of the Lebensmittel-, Bedarfsgegenstände- und Futtermittelgesetzbuch is to protect the health of the consumer by taking precautionary measures. Furthermore it aims at protecting the consumer from misleading information in relation to foodstuffs. The law prohibits the production of any foodstuffs, which can be harmful for the health of the consumer. In addition the law also prohibits the production of any foodstuffs, which have been produced in combination with non-admitted food additives. According to Paragraph 11 of the law it shall not be allowed to introduce products to the market, which contain misleading information about the composition or the content of the food, amongst others this contains the prohibition to include information that promises effects, which are not based on scientific facts. Moreover, as outlined by Paragraph 12, it is illegal to produce advertising, which is misleading in relation to, for example the abatement or the prevention of an illness or in relation to medical opinion. So-called functional food shall also not be used for the purpose of advertisement.

It can be concluded that the consumer is secured a high level of protection by the Lebensmittel-, Bedarfsgegenstände- und Futtermittelgesetzbuch in relation to misleading information on the food that is being consumed.

Next a closer look at the law regulating the labelling of foodstuffs will be taken. The Verordnung über die Kennzeichnung von Lebensmitteln, regulates the labelling of foodstuffs. 46

46 Verordnung über die Kennzeichnung von Lebensmitteln 1981. 
In Paragraph 3 of the Law a list is given, which includes the information that has to be printed on the package before it is being put on the market for the consumer to purchase. Moreover an account of the ingredients contained in the product has to be made in a specific order, which is regulated by Paragraph 6 of the Law. The list of ingredients is called the Verzeichnis der Zutaten, and requires that the list starts in descending order of weight, determined as at the time of the use of the ingredients in the preparation of the food. Additionally the added water needs to be part of the list of ingredients as well.

Furthermore the minimum durability of the product has to be clearly indicated, it refers to the date up to which the product can be consumed and still contain the specific nature of the product. The durability date is separate into two categories, the Mindeshaltbarkeitsdatum refers to the date up to which the food can best be used and the Verbrauchsdatum refers to the date up to which the food should be consumed.

In terms of the Mindeshaltbarkeitsdatum the following rules apply. If the food retains its specific properties for up to 3 months it is sufficient to indicate the durability by stating the day and the month up until which it can be consumed. If the specific properties can on the other hand still be found within the food after 3 months but not more than 18 months, the date needs to be indicated by stating the month and the year up until which it can be consumed. If the product retains it specific properties for longer than 18 months it is sufficient to indicate the durability date by the month or sometimes even only the year up until which it can be consumed. It is not necessary to indicate the Mindeshaltbarkeitsdatum in certain products, as for example fresh fruits, vegetables and alcoholic beverages. A full list of foodstuff, which does not need to have an indicated of the Mindeshaltbarkeitsdatum can be found in Paragraph 7 of the law.

The indication of the 'use by' date refers to the time up until which the food can be consumed, the Verbrauchsdatum, here the same rules as for the indication of the Mindeshaltbarkeitsdatum apply.

The law on the labelling of foodstuffs provides clear guidelines on how the product has to be labelled, and provides a high level of protection for the consumer.

In terms of the name of the food, the Verkehrsbezeichnung, it can be said that the German regime is pretty strict. The only name that can be used for the food or in the list of ingredients is the name that has been prescribed by law, as outlined in Paragraph 4 of the law. 
Lastly Paragraph 3 of the law on food labelling, the Verordnung über die Kennzeichnung von Lebensmitteln, further requires the labelling of the contained alcohol percentage and the amount of certain ingredients or kind of ingredients.

In conclusion it can be said that Germany has set a very high level of protection for its consumers, the Directives and Regulations issued by the EU have been implemented in the correct manner and can be found in the national contract law regime.

\section{United Kingdom}

\subsection{Consumer Protection}

In order to be able to outline, compare and provide an approach on the differences between the two systems it is now necessary to have a closer look at the British consumer contract law regime, including the regime on food safety regulations. Attention will be paid to the statutory provisions in the named fields.

The Consumer Safety Act of 1978 was enacted to secure safety of the consumer, in relation to defective products. During the preparation of the Act the experiences of the operation of the Consumer Protection Act of 1961 were taken into account, the Act implements the proposals for reform contained in the Consultative Document on Consumer Safety, which was presented to the Parliament in 1976.47

In 1987 the Parliament enacted the Consumer Protection Act, making significant changes to the consumer law of the UK. ${ }^{48}$ Directive $85 / 374 /$ EEC on product liability is being implemented in the first part of the Act, by introducing a regime of strict liability for damage arising from defective products. In part 2 of the Act the government is given the power to regulate the safety of consumer products through statutory instruments. Part 3 of the Act defines giving misleading price indications as a criminal offence. Section 10 of the Act protects the consumer by declaring any person guilty of an offence if he 'supplies the consumer with any goods that fail to comply with the general safety requirements', additionally it is mentioned that consumer goods are considered to 'fail to comply with

47 Barrett 1978, p. 707. 
the general safety requirements if they are not reasonably safe having regard to all circumstances'.

Furthermore, the Unfair Terms in Consumer Contracts Regulations of 1999 provides protection for the consumer by implementing Directive 93/13/EEC. The rules set out in the Directive are in several ways narrower than the rules that are already in place under the British regime. However the Directive does extent the scope of the terms that are rendered as being ineffective. Directive 93/13/EEC has been addressed more extensively before and therefore its provisions will not be repeated at this point. It is worth mentioning though that it seems to have increased at least a small part of the already existing law on consumer protection.

Moreover there is the Consumer Credit Act of 1974, which has been established for the protection of the consumers in relation to credit. New forms of protection for the consumer as well as new regulations for bodies trading in consumer credit and related industries have been introduced by the Act. ${ }^{49}$

Additionally the Consumer Protection from Unfair Trading Regulations 2008 prohibits all kinds of unfair commercial practices. Section 3 of the Act outlines what constitutes an unfair commercial practice. Furthermore it includes misleading actions as being unfair.

Finally it can be said that the regime governing consumer protection in the UK is quite high, and in most fields higher than the minimum level of consumer protection issued by the EU.

\subsection{Food Safety Regulations in the United Kingdom}

In the field of food safety regulation, there has been a great amount of changes over the last 20 years, which have greatly been influenced by the realization of the government to provide more transparency and increase consumer and public confidence in the regime.

Multiple food safety scandals during the period of the late 1980's up to the year 2000 were the reason behind the changes of the regime. As an attempt to regain the trust of the public a new separate, independent agency was set up, with the main objective

49 Consumer Credit Act 1974. 
of securing consumer safety. The Food Safety Agency has ever since undertaken annual surveys in order to measure the level of consumer confidence in food safety. ${ }^{50}$ The Food Safety Agency is answers to the Minister for Health. The Food Standards Agency was established through the Food Standards Act of 1999. The main purpose of the Food Standards Act of 1999 was in fact the establishment of the Agency, which is extensively addressed in the first part of the Act. Additionally the Act sets out the main objectives of the Agency, which is the protection of public health in relation to food.

In addition to the Food Safety Agency, the Department for Food and Rural Affairs was established; its primary objective is to ensure that the food supply chain is sustainable, safe and competitive. ${ }^{51}$ There are in total three main policy-making departments that are involved in securing proper food safety regulations, the Food Safety Agency, the Department for Food and Rural Affairs and the Department of Health, together they form the institutional framework of the food safety regulation in the UK..$^{52}$

As well as in Germany the UK also provides a separation between risk assessment and risk management, which are governed by scientific advisory committees. However a complete separation of the two has not yet been achieved in the UK. The three departments mentioned above have published statements on how risk assessment should be carried out within the individual departments. The issue of risk management deals with the policy-based process, it involves political, cultural, technical and socio-economic issues.

In relation to labelling of foodstuffs the Food Labelling Regulations of 1996 deals with the matter. Paragraph 5 of the Regulation deals with the general labelling requirement of food. The food that is being presented to the consumer needs be labelled with the name of the food, the list of the ingredients contained in it, the appropriate durability of the food, any special storage conditions or conditions of use, the name and address of the manufacturer and particulars of the place of origin of the food need to be indicated. Additionally as indicated in subsection (g) of Paragraph 5, 'instructions for use if it would be difficult to make appropriate use of the food in the absence of such instructions'.

Furthermore if a certain name is prescribed to the food by law the package label has to be identical with the name prescribed by law, as outlined in Paragraph 6 of the Regulation. If however no name is prescribed to the food by law, the name given to the food in the area of origin, referred to as the customary name, shall be given to the product. If there

50 Vos \& Wendler 2006, p. 140.

51 Barling et al 2002, p.560.

52

Vos \& Wendler 2006, p.149. 
is however no prescribed name to be used by law nor a customary name for the food, the name that should be used has to be sufficiently precise in informing the consumer of the nature of the food.

The Regulation then goes into further detail about the list of ingredients and the guidelines on the list of ingredients that has to be on the product and the durability indication. In terms of the list of ingredients, it is mentioned in the Regulation that a heading of the list must be present. The law prescribes the order in which the ingredients are listed, the list should always start in descending order of weight, determined as at the time of the use of the ingredients in the preparation of the food, as outlined in Paragraph 12 and 13 of the Regulation. Moreover it is mentioned that the name of the food used in the list of ingredients has to be the name that has been prescribed to the food by law. The Regulation also indicates which foods do not need to bear a list of ingredients, such foods are for example fresh fruits or vegetables.

In relation to the durability, the minimum durability of a the food has to be indicated by the words 'best before' followed by the date up to which the food can be consumed and any storage conditions that need to be taken into account. The Date up until which the food can be consumed, the 'best before' indication has to be present, furthermore the durability has to be presented by stating the day, the month and the year. If the food retains its specific properties for up to 3 months it is sufficient to indicate the durability by stating the day and the month up until which it can be consumed. If the specific properties can on the other hand still be found within the food after 3 months but not more than 18 months, the date needs to be indicated by stating the month and the year up until which it can be consumed. If the product retains it specific properties for longer than 18 months it is sufficient to indicate the durability date by the month or sometimes even only the year up until which it can be consumed.

The indication of the 'use by' date refers to the time up until which the food can be used; the same rules as for the indication of the 'best before' date apply.

Additionally the Food Safety Agency has issued a guidance on labelling provisions in 2011. The aim of the document is to 'help all food manufacturers, producers, retailers, caterers and enforcement authorities understand the requirements of those Regulations which relate to the allergen and miscellaneous labelling provisions and to offer advice on relevant best practice.' 
In terms of misleading information the Food Labelling Regulations of 1996 addresses the issue in Part III, prohibiting any misleading information. Additionally subsection ( $f$ ) of Paragraph 5 of the Food Labelling Regulation of 1996 requires the food to be labelled, with any particulars of the place of origin or provenance of the food, any failure to indicate them might mislead a consumer to a material degree as to the origin of the product. The Paragraph therefore also prohibits any misleading information.

\section{Approaches to Consumer Protection, focus on food labelling, in Germany and the United Kingdom}

The aim of this paper is to outline how best to approach the existing differences in the level of consumer protection in a country under the common law regime and a country under the civil law regime, focusing on food safety regulations, in particular food labelling. However when looking at the comparison of the two countries, as shown above, it becomes clear that there are not as many differences as one might expect there to be. In fact the rules on food labelling, which secure the protection of the consumer, are very similar under the two regimes. In order to be able to provide a clear comparison between the two regimes the laws on food labelling and misleading information will be presented in a short table, which can be found in the annex.

When looking at the comparison of the two regimes it becomes quite clear that in the field of consumer protection secured through the laws on food labelling there are not as many differences as one might think there are. In fact when comparing the two national regimes to the laws of the EU on the matter it can be seen that the level of protection that exist for the consumer at the national level is the almost same that is being provided for by the EU.

There are however still a few differences that remain in the field of food safety regulations, these differences will however not create a great problem in case of full harmonisation in the area.

In fact it seems that the national rules that have been in place before hand, that might have secured a different level of consumer protection, whether it was higher or lower, seems to have been replaced by the standard level of protection provided for by the EU in the field. Keeping this in mind and comparing the two regimes it seems as if harmonisation in the field of food safety regulations is much more advanced then the 
average consumer might realise. In fact the laws on the labelling of food are almost identical in Germany and the UK. This is beneficial for the consumer, especially in situation where a new food scandal is taking place. If the consumer would be aware that the laws regulating the food safety in the country where the scandal has started, are the same laws which are in place at the national regime of the consumer, the consumer would not change its buying pattern because of the scandal.

It would therefore be a wise step to inform the consumer that the laws regulating food safety are the same in the two regimes that have harmonised the laws of the EU and that the same level of consumer protection is provided for in Germany and the UK. If the consumer is aware that he/she is protected in the same way in both regimes it is very likely that cross border transactions will increase since the consumer will not have to fear a lower level of protection in the other country.

In terms of consumer protection in general, there remain some differences still, however if the fields in which the consumer is protected are approached at a smaller level, as for example the laws on food labelling, harmonisation of the law will not be difficult to achieve. The level of consumer protection will over time be likely to become the same as the EU provides, therefore harmonisation is likely to be in place in the near future even without a single document containing the rules for every Member State of the EU. Harmonisation will be achieved through Directives and Regulations, which the Member States of the EU will have to implement at the national level, providing at the end the same level of consumer protection. Eventually the EU is likely to issue on single document, combining the already existing law in the field, in order to have a standard set of rules that protects the consumer.

\section{Conclusion}

As mentioned before the aim of the paper was to outline how best to approach the existing differences in the level of consumer protection in a country under the common law regime and a country under the civil law regime, focusing on food safety regulations, in particular food labelling. To achieve the highest level of consumer protection within the $\mathrm{EU}$, in order for the internal market to work properly; the following research question was addressed: "How to approach the differences in level of Consumer protection, in a civil law country compared to a country under the common law regime?". 
When looking at Union laws on the matter and the regimes of Germany and the UK it becomes clear that the differences are not as big as one might have imagined. It can be said that we have further advanced in the process of harmonisation than many of us might realise, securing a certain level of protection in the field of food safety regulations.

Through the existing EU legislation that has been issued over the last few years, which has been implemented by the Member States, a harmonised set of rules in the field has already been provided. The two Member States that have been addressed in this paper already provide for the same rules in the field of food safety regulations.

If the EU keeps issuing legislation that the Member States will implement a uniform level of consumer protection will be reached and will provide a good level of protection for the consumer. Some Member States will have to lower the level of protection they provide under the national regime of their country however it will still be beneficial for the consumer if the same rules apply to all purchases he makes. If the consumer is able to buy from any country within the EU without having to fear lower levels of protection he will benefit of the law even if this means that the standard of the level of protection will have to be lowered in his home country.

In order to draw an accurate conclusion on the matter, that includes the whole Union, it would be advisable to have a look at the level of consumer protection, amongst others in the field of food safety, of the other Member States.

Over all the practice of introducing legislation at the European Level, which the Member States then have to implement at the national level is a good way to achieve a harmonised set of rules. 


\section{Annex}

\begin{tabular}{|c|c|c|}
\hline & Germany & United Kingdom \\
\hline $\begin{array}{l}\text { Consumer } \\
\text { Protection } \\
\text { (general) }\end{array}$ & $\begin{array}{l}\text { - no solid "consumer protection act" as such } \\
\text { - consumer is protected through several } \\
\text { Articles in the BGB }\end{array}$ & $\begin{array}{l}\text { - several Acts providing protection for the } \\
\text { consumer }\end{array}$ \\
\hline \multicolumn{3}{|c|}{ Food Labeling } \\
\hline Laws & $\begin{array}{l}\text { - Verordnung über die Kennzeichnung von } \\
\text { Lebensmitteln }\end{array}$ & - Food Labelling Regulations of 1996 \\
\hline $\begin{array}{l}\text { Name of the } \\
\text { Food }\end{array}$ & $\begin{array}{l}\text { - Verkehrsbezeichnung } \\
\text { - only name that can be used for the food or } \\
\text { in the list of ingredients is the name that } \\
\text { has been prescribed by law }\end{array}$ & $\begin{array}{l}\text { - the name prescribed by law has to be used } \\
\text { for the food } 6 \\
\text { - If no name is prescribed to the food by law, } \\
\text { the name given to the food in the area of } \\
\text { origin, referred to as the customary name, } \\
\text { shall be given to the product. } \\
\text { - If there is no prescribed name to be used } \\
\text { by law nor a customary name for the } \\
\text { food, the name that should be used has } \\
\text { to be sufficiently precise in informing the } \\
\text { consumer of the nature of the food. }\end{array}$ \\
\hline $\begin{array}{l}\text { List of } \\
\text { Ingredients }\end{array}$ & $\begin{array}{l}\text { - account of the ingredients contained in the } \\
\text { product has to be made in a specific order } \\
\text { - list starts in descending order of weight, } \\
\text { determined as at the time of the use of the } \\
\text { ingredients in the preparation of the food } \\
\text { - added water needs to be part of the list of } \\
\text { ingredients as well }\end{array}$ & $\begin{array}{l}\text { - heading of the lust must be present } \\
\text { - list starts in descending order of weight, } \\
\text { determined as at the time of the use of the } \\
\text { ingredients in the preparation of the food } \\
\text { - the name of the food used in the list of } \\
\text { ingredients has to be the name that has } \\
\text { been prescribed to the food by law }\end{array}$ \\
\hline Durability & $\begin{array}{l}\text { - Mindeshaltbarkeitsdatum and } \\
\text { - food retains its specific properties for up to } \\
3 \text { months > day; month } \\
\text { - specific properties can still be found after } \\
3 \text { months but not more than } 18 \text { months > } \\
\text { month; year } \\
\text { - specific properties for longer than } 18 \\
\text { months it is sufficient to indicate the } \\
\text { durability date by the month or sometimes } \\
\text { even only the year up until which it can be } \\
\text { consumed } \\
\text { - non indication of Mindeshaltbarkeitsdatum } \\
\text { needed for some products (f.e. fruits, } \\
\text { vegetables) list of foodstuff which does not } \\
\text { need indication can be found in } \S 7 \\
\text { - 'use by' (Verbrauchsdatum ) same } \\
\text { rules as for the indication of the } \\
\text { Mindeshaltbarkeitsdatum apply }\end{array}$ & $\begin{array}{l}\text { - "Best before" and "Use by" } \\
\text { - food retains its specific properties for up to } 3 \\
\text { months > day; month } \\
\text { - specific properties can still be found after } \\
3 \text { months but not more than } 18 \text { months > } \\
\text { month; year } \\
\text { - specific properties for longer than } 18 \\
\text { months it is sufficient to indicate the } \\
\text { durability date by the month or sometimes } \\
\text { even only the year up until which it can be } \\
\text { consumed } \\
\text { - The indication of the 'use by' date refers to } \\
\text { the time up until which the food can be } \\
\text { used; the same rules as for the indication of } \\
\text { the 'best before' date apply. }\end{array}$ \\
\hline
\end{tabular}




\begin{tabular}{|c|c|c|}
\hline $\begin{array}{l}\text { Other } \\
\text { Requirements }\end{array}$ & $\begin{array}{l}\text { - labelling of the contained alcohol } \\
\text { percentage and the amount of certain } \\
\text { ingredients or kind of ingredients. }\end{array}$ & $\begin{array}{l}\text { - any special storage conditions } \\
\text { - conditions of use of the name and } \\
\text { address of the manufacturer } \\
\text { - particulars of the place of origin of the } \\
\text { food and } \\
\text { - instructions for use }\end{array}$ \\
\hline \multicolumn{3}{|c|}{ Misleading Information } \\
\hline & $\begin{array}{l}\text { - Lebensmittel-, Bedarfsgegenstände- und } \\
\text { Futtermittelgesetzbuch } \\
\text { - aims at protecting the consumer from } \\
\text { misleading information in relation to } \\
\text { foodstuffs } \$ 1 \\
\text { - not allowed to introduce products to } \\
\text { the market, which contain misleading } \\
\text { information about the composition or } \\
\text { the content of the food, amongst others } \\
\text { this contains the prohibition to include } \\
\text { information that promises effects, which } \\
\text { are not based on scientific facts }\end{array}$ & $\begin{array}{l}\text { - Food Labelling Regulations of } 1996 \\
\text { addresses the issue in Part III } \\
\text { - prohibiting any misleading information }\end{array}$ \\
\hline \multicolumn{3}{|c|}{ Risk Assessment \& Management } \\
\hline & $\begin{array}{l}\text { - separation of risk assessment and risk } \\
\text { management } \\
\text { - Federal Institution for Risk Assessment } \\
\text { issues recommendations in numerous } \\
\text { areas } \\
\text { - Federal Ministry deals with risk } \\
\text { Management in Germany for Food, } \\
\text { Agriculture and Consumer Protection, it } \\
\text { is in charge of consumer protection }\end{array}$ & $\begin{array}{l}\text { - separation between risk assessment and } \\
\text { risk management } \\
\text { - governed by scientific advisory } \\
\text { committees } \\
\text { - complete separation of the two has not } \\
\text { yet been achieved }\end{array}$ \\
\hline
\end{tabular}




\section{Bibliography}

\section{Primary Sources:}

\section{$\operatorname{COM}(2011) 635$ final}

- COM (2011), proposal for a Regulation of the European Parliament and of the Council on a Common European Sales Law, 635 final

\section{Directive 85/577/EEC}

- Directive $85 / 577 / E E C$, of the Council to protect the consumer in respect of contracts negotiated away from business premises, [1985] O.J. L.372/31

\section{Directive 87/102/EEC}

- Directive 87/102/EEC, of the Council for the approximation of the laws, regulations and administrative provisions of the Member States concerning consumer credit, [1987] O.J. L.42

\section{Directive $93 / 13$}

- Directive 93/13/EEC, of the Council on unfair terms in consumer contracts, [1993] O.J. L.95/29

\section{Directive 97/7/EC}

- Directive 97/7/EC, of the European Parliament and of the Council on the protection of consumers in respect of distance contracts, [1997] O.J. L.43

\section{Directive 97/47/EC}

- Directive 97/47/EC, of the European Parliament and of the Council on the protection of consumers in respect of distance contracts, [1997] O.J. L 144/19

\section{Directive 1999/44/EC}

- Directive 1999/44/EC, of the European Parliament and of the Council on certain aspects of the sale of consumer goods and associated, [1999] O.J. L 171/12

\section{Directive 2005/29/EC}

- Directive 2005/29/EC, of the European Parliament and of the Council concerning unfair business-to-consumer commercial practices in the internal market, [2005] O.J. L 149/22

\section{Directive 2011/83/EC}

- Directive 2011/83/EC on consumer rights, amending Council Directive 93/13/EEC and Directive 1999/44/EC of the European Parliament and of the Council and repealing Council Directive 85/577/EEC and Directive 97/7/EC of the European Parliament and of the Council, [2011] O.J. L. 304/64 


\section{Regulation $178 / 2002$}

- Regulation 178/2002, of the European Parliament and of the Council, laying down the general principles and requirements of food law, establishing the European Food Safety Authority and laying down procedures in matters of food safety, [2002], O.J. L 31.1

Regulation 1169/2011

- Regulation 1169/2011, of the European Parlimanet and of the Council on the provision of food information to consumers [2011] O.J. L. 304/18

\section{Secondary Sources:}

\section{Barling 2002}

- D. Barling et al., 'Joined-up Food Policy? The Trials of Governance, Public Policy and the Food System', 36 Social Policy \& Administration 6 (2002)

\section{Barrett 1978}

- B. Barrett, 'Consumer Safety Act 1978', 41 The Modern Law Review 6 (1978)

\section{Ciceronis 1827}

- M.T. Ciceronis, De Republica, (Lipsiae, 1827)

Collins 2008

- H. Collins, Standard Contract Terms in Europe: A Basis for and a Challenge to European Contract Law, (Kluwer, 2008)

\section{Goode 2003}

- R. Goode, Contract and Commercial Law: the Logic and Limits of Harmonisatio, (Metro, 2003)

\section{Gomez \& Ganuza 2011}

- Gomez \& Ganuza, An Economic Analysis of Harmonization Regimes: Full Harmonization, Minimum Harmonization or Optional Instrumen, 2011

Lando 2000

- O. Lando, 'Optional or mandatory Europeanisation of contract law' 8 European Review of Private Law (2000)

Lando 1985

- O. Lando, 'The Lex Mercatoria in International Commercial Arbitration', 34 The International and Comparative Law Quarterly 4 (1985)

\section{Reich 2011}

- N. Reich, 'Harmonisation of European contract law: with special emphasis on consumer law', 1 China-EU Law Journal 2 (2011) 
Smits 2012

- J. Smits, 'Introduction to special issue: Harmonisation of contract law: an economic and behavioural perspective' 33 European Journal of Law and Economics 3 (2012)

Vogenauer \& Weatherhill 2006

- S.Vogenauer \& S. Weatherill, The Harmonisation of European Contract Law-Implications for European Private Laws, Business and Legal Practice, (Hart Publishing 2006)

Vos \& Wendler 2006

- E.Vos \& F. Wendler, Food Safety Regulation in Europe. A Comparative Institutional Analysis, (Intersentia, 2006)

\section{Internet Sources:}

\section{W.Wippermann 2001}

- Wippermann, 125 Jahre "Institut für gesundheitlichen Verbraucherschutz und Veterinärmedizin" -3000 Jahre Geschichte des Verbraucherschutzes, 2001, retrieved via http://www.bfr.bund.de/cm/343/wippermann_vortrag.pdf, last visited 13.07.2013

Health \& Consumer Protection Directorate- General

- Health \& Consumer Protection Directorate- General 'Consumer Protection in the European Union: Ten Basic Principles', retrieved via http://ec.europa.eu/consumers/cons_info/10principles/en.pdf, last visited 13.07.2013 